Working Paper No. 545, 2001

\title{
Privatization and Foreign Competition
}

by Pehr-Johan Norbäck and Lars Persson

IUI, The Research Institute of Industrial Economics

P.O. Box 5501

SE-114 85 Stockholm

Sweden 


\title{
Privatization and Foreign Competition
}

\author{
Pehr-Johan Norbäck and Lars Persson ${ }^{*}$ \\ The Research Institute of Industrial Economics
}

February 2, 2001

\begin{abstract}
A bstract
This paper determines the equilibrium market structure in a mixed international oligopoly, where the state assets are sold at an auction. The model suggests that low greenfield costs and low trade costs induce foreign acquisitions. The intuition is that domestic firms can then not prevent foreign firms from becoming strong competitors and thus, their willingness to pay for the state assets is low. We also find that profit shifting from domestic to foreign firms generated by National Treatments clauses is partly paid for by the foreign investor in the bidding competition over the state assets.
\end{abstract}

Keywords: Privatization, Failing Firms, FDI, Acquisitions, National Treatment.

JEL classification: F23, L13, L33

${ }^{*}$ We have benefitted from useful comments from Henrik Braconier, Karolina Ekholm, SvenOlof Fridolfsson, Henrik Horn, Dan Kovenock, Massimo Motta, Johan Stennek, and participants in seminars at the Institute for International Economic Studies (Stockholm), WZB (Berlin), 2000 CEPR and IUI Mergers and Competition Workshop (Stockholm), and European University Institute (Florence). Thanks to Christina Lönnblad for improving the language. Financial support from the Bank of Sweden Tercentenary Foundation, and Tom Hedelius' and Jan Wallander's Research Foundations, is gratefully acknowledged. (priv-imp24.tex)

†Pehr-Johan Norbäck and Lars Persson, the Research Institute of Industrial Economics Box 5501 SE-114 85 Stockholm. E-mail: larsp@iui.se and PJN@iui.se, Internet: www.iui.se. 


\section{Introduction}

Privatizations have become an important part of industrial restructuring in all parts of the world. Since 1990, European governments have sold more than $\$ 450$ billion-worth of state assets in many different sectors, including the banking, insurance, telecommunication and automobile industries. Many countries also announce substantial forthcoming privatizations. ${ }^{1}$

In what follows, with privatizations we refer to the selling of state assets. This definition incorporates the selling of state owned enterprises but also includes cases where the government has stepped in to rescue a failing firm which has later been sold off. In South Korea, for instance, the government has recently sold the failing car producers Daewoo and Kia.

Foreign competition is an important element in many of these sales. In Europe, on average, about $30 \%$ of the privatized firms in the 1990's were acquired by foreign investors. Moreover, in many of the sales, bidding competition between domestic and foreign investors took place. In South Korea, the domestic carproducer Hyundai acquired Kia in competition with FORD. (The Economist, 1998). Later, FORD outbid alliances formed by Daimler-Chrysler and Hyundai and GM and FIAT, and acquired Daewoo.(Financial Times, 2000). ${ }^{2}$

Many of these privatizations take place in a time of on-going investment and

\footnotetext{
${ }^{1}$ In the first seven months of the year 2000, about 150 privatizations was under way in the EU (Thompson Financial Securities). Still more privatizations are to be expected. In Greece, for instance, a large privatization program is discussed as part of a structural reform before joining the euro-zone. ( FT Euro, 1999 and the The Economist, 2000).

${ }^{2}$ Other examples include the privatization of the Italian car producer Alfa Romeo in 1987, where FIAT did outbid FORD (Thompson Financial Securities). The Swedish postal state company's banking division, Postgirot, is about to be sold to an alliance of Swedish banks in competition with several foreign competitors (Dagens Industri, 2000).
} 
trade liberalization. ${ }^{3}$ This suggests that the outcome of the sale of the state assets will interact with the pattern of foreign direct investment (FDI) and international trade. The purpose of this paper is to analyze this interaction. To this end, we consider a two-country partial equilibrium model. At the outset, a stateowned enterprise and a privately owned domestic firm are located in the domestic market. There is also a foreign firm located in a foreign country. It is assumed that the government in the domestic country will deregulate the market through a program with two distinct measures: (i) selling the state assets, and (ii) allowing for new plants to be opened by foreigners, i.e. allowing for greenfield investments by reducing investment restrictions. In the first stage, the state assets are sold at a simultaneous bid auction, where the two private firms are potential buyers. ${ }^{4}$ In the second stage, the foreign firm can expand by investing greenfield, i.e. setting up a new plant, if it did not obtain the state assets in the first stage. In the third stage, the firms sell a homogenous product and the foreign firm faces a trade cost in addition to its normal production costs, if it has not invested in the market. ${ }^{5}$

\footnotetext{
${ }^{3}$ The trend towards greater liberalization has been strong in recent years. Over the period 1991-1996, approximately 95 per cent of a total of 599 changes in the regulatory FDI regimes of countries were in the direction of liberalization. The changes mostly involved the opening of industries previously closed to FDI (World Investment Report 1997).

${ }^{4}$ In this case, the identity of the buyer affects the profits of all firms. This interdependence constitutes a fundamental difficulty when determining the buyer, since the price a potential buyer is willing to pay for the assets depends on who might otherwise obtain them. Our study will use the approach taken by Jehiel and Moldovanu (1996), who analyze auctions where the bidders' valuations of an auctioned item depend on the other bidders' identities.

${ }^{5}$ It is not necessary to assume greenfield investment to previously have been forbidden, what is required is that greenfield costs have initially been high enough to prevent greenfield entry and that such costs might be reduced.

Moreover, for the main results in the paper, it is not necessary to assume that the privatization takes place before the greenfield investment liberalization. What is required, is that, at the time of the deregulation, the foreign firm is located outside the domestic market.
} 
Our main result is that low greenfield costs and low trade cost induce foreign acquisitions. This seems counterintuitive at first sight, since lower greenfield costs would be expected to lead to more greenfield entry rather than entry by acquisition, and that lower trade costs would lead to more exports rather than entry. ${ }^{6}$ However, this result is intuitive, when taking into account that the levels of greenfield costs and trade costs affect the acquisition price. In order to explain the effect of the trade cost, consider a situation where greenfield costs are high enough to prevent greenfield entry. In this situation, the domestic firm is willing to pay a high price for the state assets when trade costs are high, since the foreign firm must then export facing high trade costs. However, when trade costs are low, the domestic firm can no longer prevent the foreign firm from becoming a strong competitor and thus, its willingness to pay for the state assets decreases. Similarly, when greenfield cost are low, the domestic firm cannot prevent the foreign firm from becoming a locally strong competitor and thus, its willingness to pay for the state assets is low. Consequently, a foreign acquisition becomes more likely when trade and greenfield costs are low. ${ }^{7}$

Acquisitions by foreign firms in privatizations are not only quantitatively significant; in policy making they are also often viewed differently than those made by domestic firms. For instance, many countries restrict the right of foreign individuals and firms to acquire domestic firms, or apply special restrictions to foreign firms in certain industries. On the other hand, many countries negotiate over so called "National Treatment" (NT) clauses, which set out the commitments of countries to treat foreign-controlled firms operating in their territories no less

\footnotetext{
${ }^{6}$ See, for instance, Horstmann and Markusen (1992), Markusen and Venables (1998) and Motta (1992) for papers dealing with the trade off between exports and FDI.

${ }^{7}$ Horn and Persson (2000) showed that domestic firms have incentives to merge for sufficiently high trade barriers in order to prevent international mergers in a merger formation model without greenfield investment.
} 
favorably than domestic enterprises in similar situations. ${ }^{8}$

In the policy debate, NT has been questioned on the ground that it might lead to FDI which "crowd out" domestic investments and shift profits from domestic to foreign firms. ${ }^{9}$ Moreover, it has been shown in the theoretical literature on MNEs that FDI, under some circumstances, can reduce domestic welfare due to profit shifts from domestic to foreign firms. ${ }^{10}$ Here, we will illuminate this issue in the context of privatizations. We show that crowding out is partly mitigated when entry takes place through an acquisition. The reason is that the foreign firm pays a price for the state assets equal to the domestic firm's valuation of the assets. But the domestic firm's valuation of the assets is precisely the negative impact on this firm through the decline in profits created by the foreign acquisition. This result illustrates a fundamental difference between foreign entry in the context of acquisition and greenfield investment. In the case where only greenfield entry is an option, the foreign firm will pay a fixed entry cost which only covers the opportunity cost in terms of factor inputs. However, the negative effect on the domestic firm's profit is not "paid for". Consequently, the argument that a national treatment clause will be detrimental to domestic welfare by shifting profits from domestic agents to foreign firms seems less relevant when applied to privatizations.

\footnotetext{
${ }^{8}$ For instance, Bolivia and the United States signed a bilateral treaty in April 1998 including a national treatment clause. Article II.1 in this treaty states: "With respect to the establishment, acquisition, expansion, management, conduct, operation and sale or other disposition of covered investments, each Party shall accord treatment no less favorable than it accords, in like situations, to investments in its territory of its own nationals or companies (hereinafter "national treatment")..." (World Investment Report 1999).

${ }^{9}$ See World Investment Report 1999. Moreover, deregulation and privatization was one of the main subjects discussed in the pre-UNCTAD X Seminar 1999.

${ }^{10}$ See, for instance, Horstmann and Markusen (1992). Note that FDI increases domestic welfare in many circumstances in these models.
} 
The related theoretical literature on foreign direct investment (FDI) and multinational enterprises (MNE) is surveyed in Markusen (1995). However, this literature does not explicitly address the question of whether entry into a foreign market is greenfield or through the acquisition of assets already in the market, or both. This issue is at focus in our study, however. ${ }^{11}$ Furthermore, to our knowledge, no paper in the privatization literature deals with determining the equilibrium buyer in a situation where the potential buyers compete in an international oligopoly. ${ }^{12}$

The model is spelled out in Section 2. In Section 3, we derive the equilibrium market structure. In Section 4, we make some observations concerning privatization, investment and trade policies. Section 5 discusses the robustness of some of the results in the paper. Section 6 concludes. Finally, most proofs appear in the Appendix.

\section{The M odel}

There are two countries, country $\mathrm{H}$ and country F. At the outset, a state-owned enterprise and a privately owned domestic firm, firm $d$, are located in a market in country $\mathrm{H}$. There is also a foreign firm, firm $f$, located in country $\mathrm{F}$. In the following, we shall focus the analysis on the market in country H. It is assumed that the government in country $\mathrm{H}$ will liberalize the market through a program

\footnotetext{
${ }^{11}$ The paper by Horn and Persson (2000) is related to our study, but in that paper, FDI takes place only by acquistions. See Bjorvatn (2000) and Görg (1997) for papers addressing the choice of entry mode into foreign markets. However, in these models, a foreign firm is exogenously assigned to be the acquirer. Thus, the equilibrium buyer is not endogenously determined.

${ }^{12}$ For overviews of the privatization literature see, for instance, Schmidt and Schnitzer (1997) and Vickers and Yarrow (1991).

Cornelli and Li (1997) analyze the optimal schemes for privatization of state enterprises when foreign investors are potential buyers. However, they do not explicitly model the product market, and thus abstract from how the privatization outcome interacts with FDI and trade.
} 
with two distinct measures: (i) selling the state assets, and (ii) allowing for new plants to be opened by foreigners, i.e. allowing for greenfield investments by abolishing investment restrictions. It is not necessary to assume that greenfield investments were previously forbidden. What is required is that the greenfield costs have initially been high enough to prevent greenfield entry and that such costs might be reduced. ${ }^{13}$

As illustrated in figure 2.1, the interaction takes place in three stages. In the first stage, the government sells the state assets, denoted $k_{S}$, in one piece at an auction where the domestic firm and the foreign firm are the two potential buyers. In the second stage, the foreign firm has the option to invest in new private assets, denoted $k_{P}$, in country $\mathrm{H}$, i.e. to undertake greenfield investments. In order to simplify the analysis, investment is assumed to be a dichotomous choice. ${ }^{14}$ Finally, in the third stage, both firms sell a homogenous product in the market in country $\mathrm{H}$ and the foreign firm faces a trade cost in addition to its normal production costs, unless it has invested greenfield. ${ }^{15}$

Section 2.1 describes the oligopoly market, and the following section presents the privatization procedure.

\footnotetext{
${ }^{13}$ Note also that it is of no consequence whether the market was previously open to imports or not.

${ }^{14}$ It can be shown that the main findings in this paper would also be valid when capital is a continuous variable. However, the derivations then become much more tedious.

${ }^{15}$ The choice of timing between the acquisition and the greenfield investment is not obvious in a general setting. In this particular application, however, it seems natural for the acquisition decision to be made before the foreign firm's greenfield decision, since the assets for sale already exist in the market and entering greenfield requires the construction of a new plant, which is usually time consuming.

Note also that for the results in this paper, it is not necessary to assume that privatization takes place before the greenfield investment liberalization. What is required, is that the foreign firm is located outside the country at the time of the deregulation.
} 


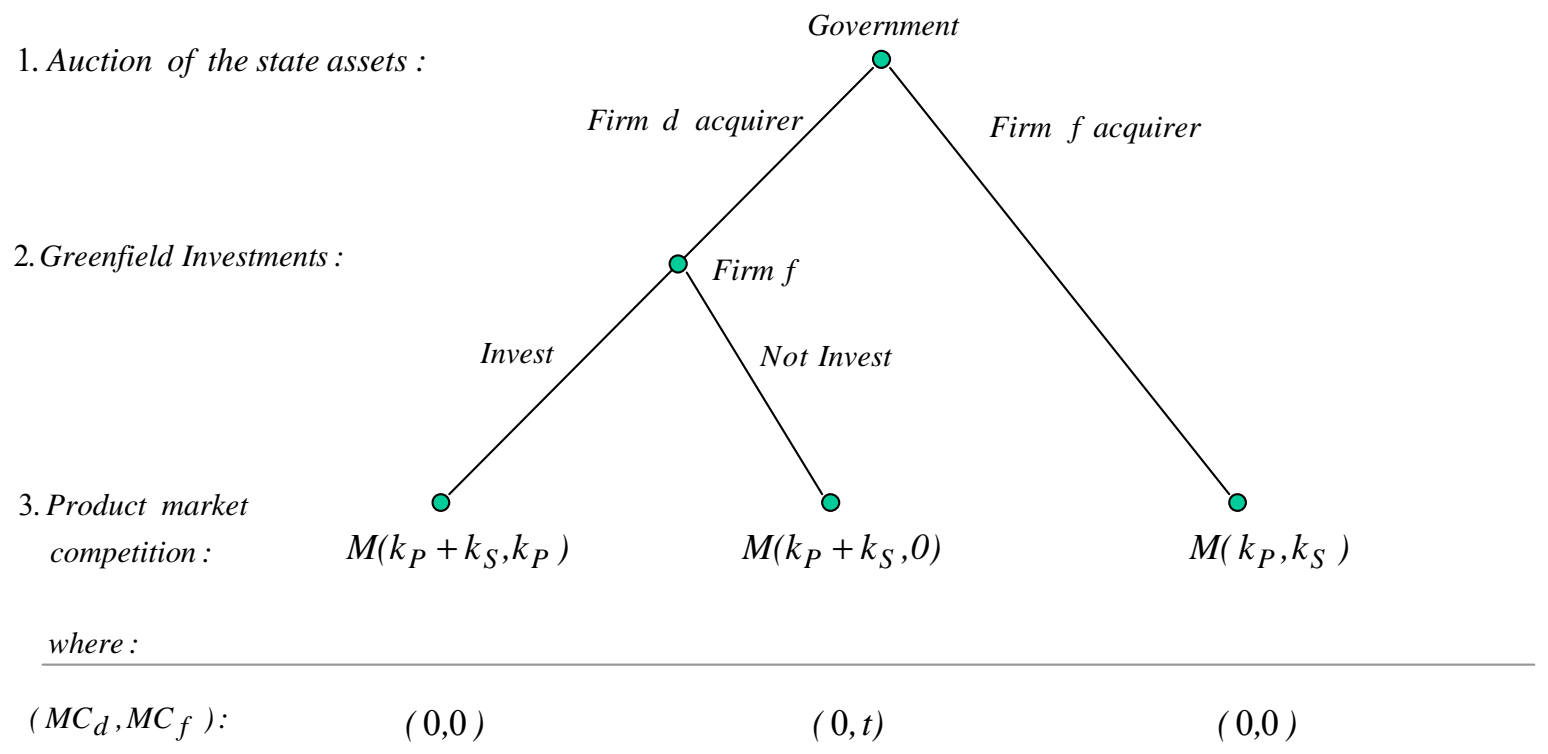

Figure 2.1: The three-stage game.

\subsection{The Oligopoly market}

In the third stage, firms compete in Cournot fashion in a homogenous good market. We assume firms to face a concave inverse demand function, so that $P^{\prime}(Q)<0$ and $P^{\prime \prime}(Q) \leq 0$. Initially, each firm possesses one unit of private assets $k_{P}$ in its respective home country. In Lemma 1 , it is shown that the state assets will be sold at the auction in equilibrium. As illustrated by figure 2.1, this implies that three different market structures are to be considered. ${ }^{16}$ To keep track of these, we denote the market structure where the domestic firm possesses $k_{d}$ units of assets and the foreign firm possesses $k_{f}$ units in country $\mathrm{H}$, by $M\left(k_{d}, k_{f}\right)$. For example,

\footnotetext{
${ }^{16}$ Note that a merger between the domestic and the foreign firm is ruled out. There are two basic ways in which a monopoly can be ruled out. One is to assume that the monopoly makes a smaller profit than the combined profits of less concentrated structures. The second reason why a monopoly may not be formed is that such a merger would not be permitted by the competition authorities. For simplicity, we stick to the latter interpretation.
} 
$M\left(k_{P}+k_{S}, 0\right)$ is then the duopoly where the domestic firm owns both private assets and the state assets, while the foreign firm has no assets in country $\mathrm{H}$ and exports from country F.

The last row in figure 2.1 refers to the firms' marginal costs in the different market structures. A firm possessing at least one unit of assets is assumed to produce at zero marginal cost. However, the foreign firm has a cost disadvantage, $t$, per unit of output when serving the market from country $\mathrm{F}$, where $t$ captures the trade cost. We assume that the foreign firm can avoid trade costs when owning assets in country $\mathrm{H}$, which can be achieved by acquiring the state assets $k_{S}$ or entering greenfield. ${ }^{17}$ To highlight the trade cost effects, we assume that expanding above one unit of assets entails no production cost reduction.

Let $\pi_{i}^{D}(t)$ denote the duopoly profit for firm $i=d, f$ when the domestic firm faces a variable cost of zero and the foreign firm faces a variable cost of $t$, and let $t^{\max }$ be the $t$ satisfying $q_{f}(t)=0 . \pi^{M}$ denotes the monopoly profit when the monopolist faces a zero production cost.

\subsection{The greenfield investments}

At this stage, the foreign firm might undertake a greenfield investment at a fixed cost $G$, if it did not obtain the state assets in period 1 . The foreign firm then lowers its costs from $t$ to 0 , by investing greenfield. Define $\bar{G}(t)$ as the value of the greenfield cost, such that the foreign firm is indifferent between the alternatives of supplying the market by exports, or by investing in new assets, $k_{P}$, and producing

\footnotetext{
${ }^{17}$ Note that operating a new plant and operating the formerly state owned enterprise incur the same marginal cost. A firm is then implicitly assumed to also possess a firm-specific asset in terms of technology. This technology can then easily be transferred to different production units within the firm (see, Markusen (1995)). Even if there were a symmetric fixed cost associated with restructuring the state-assets to make them as efficient as the new assets, the results in this section would still hold.
} 
for the market locally. Formally, we thus have:

$$
\bar{G}(t)= \begin{cases}\pi_{f}^{D}(0)-\pi_{f}^{D}(t) & \text { if } t<t^{\max } \\ \pi_{f}^{D}(0) & \text { if } t \geq t^{\max } .\end{cases}
$$

Since export profits $\pi_{f}^{D}(t)$ decrease monotonically in $t$, the critical greenfield cost $\bar{G}(t)$ is increasing in $t$ and reaches its maximum at $t=t^{\max }$. For $t>t^{\max }$, the good is not exported and $\bar{G}(t)=\pi_{f}^{D}(0)$.

\subsection{The privatization procedure}

In practise, different types of measures have been used to privatize former stateowned enterprises. Several western countries employed various kinds of auctions to sell state-owned enterprises to the highest bidder. In some transition countries, a substantial fraction of the shares of all firms were given to the general population for free. In Eastern Germany, the Treuhandanstalt bargained on the terms of trade and negotiated employment and investment guarantees. Most privatization programs combined several elements of these basic methods. ${ }^{18}$ In order to focus on the market forces as the determinant of the equilibrium buyer and the equilibrium market structure, we assume that the government sells the state assets to the highest bidder at an auction. More specifically, the privatization process is depicted as an auction where the two firms post bids and the bidder with the highest bid obtains the state assets. The winning buyer pays an amount equal to his bid. The bids are assumed to be made simultaneously. ${ }^{19}$

\footnotetext{
${ }^{18}$ See Schmidt and Schnitzer (1997).

${ }^{19}$ All firms are completely informed about their own and other firms' characteristics. This allows us to clearly attribute the market force effects, as opposed to, say, problems of incomplete information. Moreover, almost no literature derives optimal mechanisms for the selling of objects which cause externalities on other potential buyers. As far as we know, Jehiel, Moldovanu and Stacchetti (1996) and (1999) are the only papers on this subject.
} 
A bid (strategy) by one of the potential buyers is a real number $b_{i} \in R$. The sales mechanism $\alpha$ of the government is a function from $R^{2}$ to $\{1,2\}$, defining a winner.

\section{Definition 1. The sales mechanism $\alpha$ allocates the state assets to the firm post- ing the highest bid for the assets. If more than one firm posts such a bid, each such firm obtains the assets with equal probability.}

The auctions will be solved for Nash equilibria in undominated pure strategies. There is assumed to be a smallest monetary unit, denoted $\varepsilon$. We assume ties to be randomly broken, and all equalities in valuations to be ruled out. The smallest amount $\varepsilon$ is chosen such that all inequalities are preserved if $\varepsilon$ is added or subtracted.

Let us now turn to the firms' valuations of an arbitrary distribution of the state assets. Generally, these valuations do not only depend on the identity of firm $i$, but also on the identity of the firm that will obtain the assets if firm $i$ does not. Some notation is required in order to define a firm's valuation. The case where the state assets are liquidated is used as a reference point for interpretational convenience, and the profit for firm $i$ is then denoted $\pi_{i 0}$. Similarly, we let $\pi_{i j}$ denote the profit made by firm $i$ when firm $j$ has acquired the state assets and $\pi_{i i}$ the profit made by firm $i$ when it has acquired the state assets itself. Then, the valuation for firm $i, v_{i j}$, is defined:

Definition 2. $v_{i j} \equiv \pi_{i i}-\pi_{i j}$

We can rewrite $v_{i j}=\left(\pi_{i i}-\pi_{i 0}\right)+\left(\pi_{i 0}-\pi_{i j}\right)$. Thus, the valuation of obtaining the assets for firm $i$ is the profit increase caused by its asset expansion plus the change in profits avoided by preventing firm $j$ from acquiring the state assets. 
In the case with two firms in the industry, the analysis is straightforward as is shown by the following lemma: ${ }^{20}$

Lemma 1. Let firm $i$ be the firm with the highest valuation. The state assets are then acquired by firm $i$, at a price equal to the other firm's, firm $j$ 's, valuation of obtaining the state assets instead of firm $i, v_{j i}$.

Proof. See the Appendix.

\section{The equilibrium market structure}

To proceed, one more definition is required. To this end consider the situation where no greenfield investment takes place. Let $t^{*}$ be the value of the trade cost satisfying the following equality: $v_{f d}=\pi_{f}^{D}(0)-\pi_{f}^{D}(t)=\pi_{d}^{D}(t)-\pi_{d}^{D}(0)=v_{f d}$. Thus, $t^{*}$ is the trade cost at which the foreign and the domestic firms' valuations of the state assets coincide, given that no greenfield investment takes place. We are now set to derive the equilibrium market structures in the international oligopoly presented above. The game is solved backwards and the following Proposition identifies the equilibrium buyer, the equilibrium market structure and the equilibrium auction price.

Proposition 1. The equilibrium buyer, the equilibrium auction price and the equilibrium market structure are as follows:

(i) If $G>\bar{G}(t)$ and $t>t^{*}$, the domestic firm obtains the assets at a price $v_{f d}=\pi_{f}^{D}(0)$, when $t \geq t^{\max }$, and at a price $v_{f d}=\pi_{f}^{D}(0)-\pi_{f}^{D}(t)$, when $t<t^{\max }$. The market structure is $M\left(k_{P}+k_{S}, 0\right)$.

\footnotetext{
${ }^{20}$ Note that the analysis becomes much more involved when there are three potential buyers or more, since there might then exist multiple equilibria.
} 
(ii) If $G>\bar{G}(t)$ and $t<t^{*}$, the foreign firm obtains the assets at a price $v_{d f}=\pi_{d}^{D}(t)-\pi_{d}^{D}(0)$. The market structure is $M\left(k_{P}, k_{S}\right)$.

(iii) If $G<\bar{G}(t)$, the foreign firm obtains the assets at a price $v_{d f}=0$. The market structure is $M\left(k_{P}, k_{S}\right)$.

Proof. See the Appendix.

Proposition 1 contains several noteworthy features. First, in the case where the greenfield costs are high, i.e. when $G>\bar{G}(t)$, the Proposition shows that at sufficiently large trade costs, the domestic firm obtains the state assets despite the fact that the foreign firm would save considerably on trade cost by obtaining them. However, once the trade costs become sufficiently high, this trade-cost saving effect is dominated by an anti-competitive effect. The reason is that when obtaining the state assets in this situation, the domestic firm gains high market power in the product market, since it faces a competitor with high trade costs. Consequently, the domestic firm obtains the state assets.

Second, in the case with low greenfield costs, i.e. when $G<\bar{G}(t)$, the Proposition shows that the foreign firm obtains the state assets. The foreign firm will now switch from exports to greenfield production in the case where it has not obtained the state-assets. This implies that the domestic firm can no longer prevent the foreign firm from enhancing its competitiveness in the product market and is thus not willing to pay a high price for the state assets.

\subsection{W hy do low greenfield costs and low trade costs induce foreign acquisitions?}

The model above suggests that low greenfield costs and low trade costs induce foreign acquisitions. This seems counterintuitive at first sight, since lower greenfield costs would be expected to lead to more greenfield entry rather than entry by 
acquisition, and that lower trade costs would lead to more exports rather than entry. However, below this result is shown to be intuitive, when taking into account that the levels of greenfield costs and trade costs affect the acquisition price.

First, observe that the aggregate profits in the different market structures play an important role for determining the equilibrium buyer. To see this, note that Lemma 1 implies that the firm with the highest valuation obtains the state assets. Then, note that $v_{i j}>v_{j i}$ iff $\pi_{i i}+\pi_{j i}>\pi_{j j}+\pi_{i j}$, so that $v_{i j}>v_{j i}$ iff $\Pi_{i}>\Pi_{j}$, where $\Pi_{i}$ is the aggregate profit when firm $i$ obtains the state assets and $\Pi_{j}$ is the aggregate profit when firm $j$ obtains them. Thus, the aggregate profit in the market will play an important role for determining the equilibrium buyer. ${ }^{21}$

The aggregate profits in the different possible market structures are illustrated in fig 3.1. First, turn to the diagram in the middle, fig 3.1(ii). Note that the aggregate profit and thus the firms' valuations depend on the foreign firm's decision to invest greenfield in stage two (c.f figure 2.1). Making use of $\bar{G}(t)$, defined in (2.1) as the investment cost $G$ which makes the foreign firm indifferent between greenfield investment and exports, we have two cases to consider. This is illustrated in fig 3.1(ii), where $\bar{G}(t)$ is traced out in the $t G$-space. Points above $\bar{G}(t)$ then correspond to the case when greenfield investment is not profitable, whereas points below $\bar{G}(t)$ correspond to the case where it is. Figures 3.1(i) and (ii) depict aggregate profits in each of these cases. In the ensuing subsections, we will study at the two separate cases more closely.

\subsubsection{High greenfield costs}

Let us now characterize aggregate profits when the foreign firm will not invest greenfield in stage 2 upon losing the auction in stage 1, as investment costs are

\footnotetext{
${ }^{21}$ Fosfuri et al (2000) show that the aggregate profit will determine whether a MNE will export or invest abroad by instructing local workers.
} 

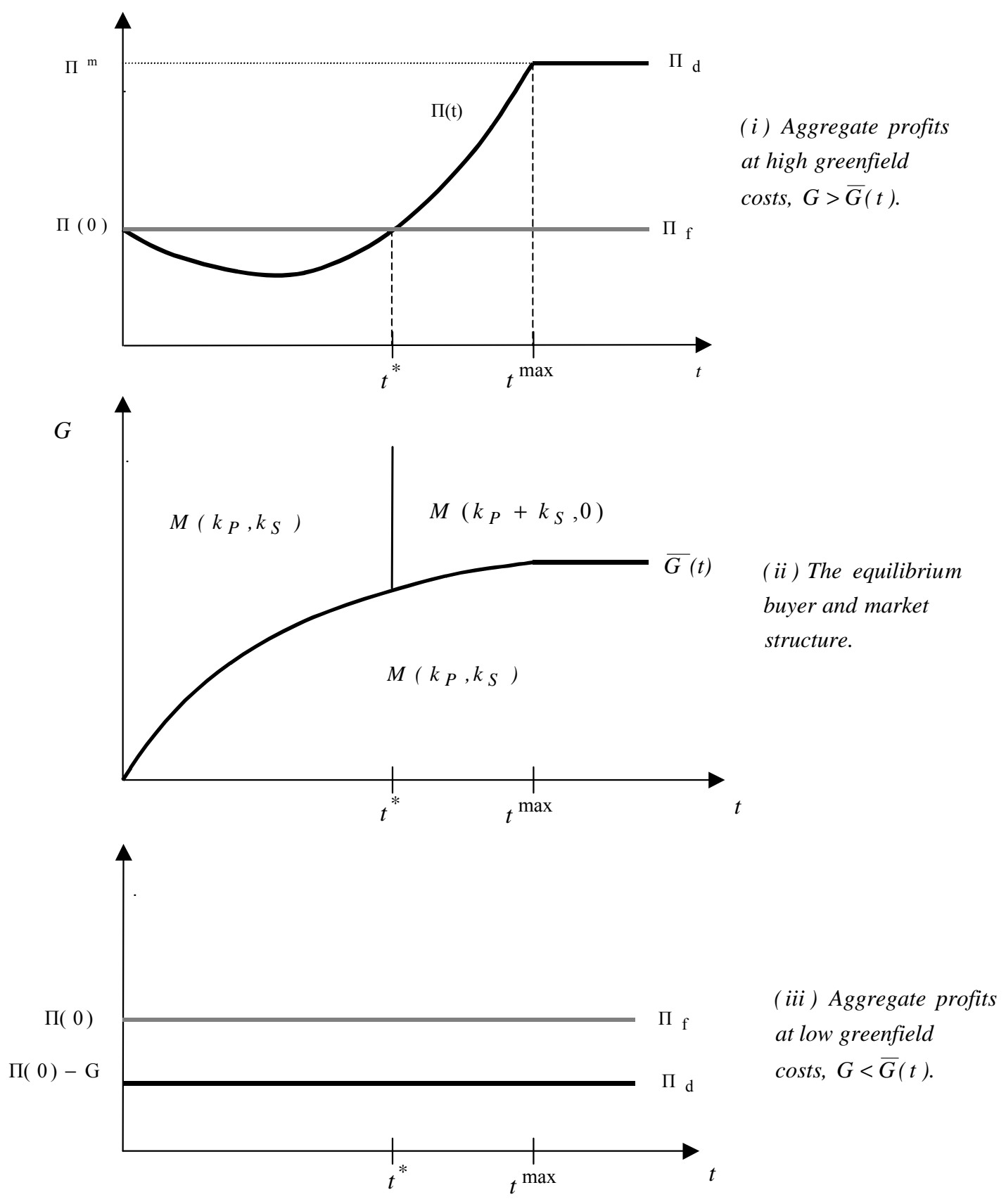

Figure 3.1: The equilibrium market structure and aggregate profits. 
too high, i.e. $G>\bar{G}(t)$. When the foreign firm is the buyer of the state assets, trade costs do no to affect aggregate profits and $\Pi_{f}=\Pi(0)$. If the domestic firm obtains the state assets, trade costs do affect aggregate profits, since the foreign firm will export. The aggregate profit in this case is given by $\Pi_{d}=\Pi(t)$, corresponding to the U-shaped curve in figure 3.1(i).

To explain the shape of aggregate profit in the latter case, let the aggregate profit be expressed as $\Pi(t)=P\left(q_{d}+q_{f}\right) q_{d}+P\left(q_{d}+q_{f}\right) q_{f}-t q_{f}$. As shown in the Appendix, differentiating $\Pi$ with respect to $q_{d}, q_{f}$, and $t$ and using the foc's yields:

$$
\frac{d \Pi(t)}{d t}=\frac{d Q}{d t} P^{\prime} q_{d}+\frac{d q_{d}}{d t} t-q_{f}
$$

The first term in Equation (3.1) captures the anti-competitive effect due to the fact that an increased trade cost induces the foreign firm to be less aggressive in its market interaction, which softens competition and increases the revenues for the domestic firm. The second term reflects the decrease in total trade costs as the domestic firm steals business from the foreign firm. This effect is referred to as the business stealing effect. The third term, the direct trade cost effect, reduces aggregate profits relative to the initial position, as the foreign firm faces higher trade costs.

The U-shape of $\Pi(t)$ can then be understood as follows. When $t$ is zero, the sales of the foreign firm are large and an increase in trade costs $t$ has a relatively strong negative impact on aggregate profits through the direct trade cost effect. In addition, the business stealing effect is zero, since the firms' costs are the same. Moreover, the anti-competitive effect is limited, for the increased market price induced by reduced industry supply then affects a smaller number of units produced by the domestic firm.

It turns out that at $t=0$, the trade cost effect dominates the anti-competitive 
effect. At higher trade costs, however, the direct trade cost effect is weaker since the foreign firm's exports are smaller. On the other hand, both the anticompetitive and the business stealing effects are stronger, since the domestic firm has a larger market share, and each unit shifted from the foreign firm to the domestic firm implies larger cost savings. Hence, aggregate profits will rise, once trade costs become sufficiently high. When trade costs become sufficiently high at $t=t^{\max }$, the domestic firm becomes a monopolist and aggregate profits are maximized.

Whether aggregate profits are maximized with the domestic or the foreign firms as the buyer depends on the balance between the incentive to form $\Pi(0)$ to avoid the higher trade cost, and the anti-competitive and business stealing incentive to form $\Pi(t)$. Comparing $\Pi_{d}=\Pi(t)$ and $\Pi_{f}=\Pi(0)$ in figure 3.1(i), we can state the following Lemma.

\section{Lemma 2. Assume that $G>\bar{G}(t)$, then}

(i): $\Pi_{d}>\Pi_{f}$ if $t \geq t^{*}$

(ii): $\Pi_{f}>\Pi_{d}$ if $t<t^{*}$

Proof. See Appendix

When trade costs are low, the domestic firm can no longer prevent the foreign firm from becoming a tough competitor and thus, its willingness to pay for the state assets decreases. Consequently, a foreign acquisition is then more likely.

\subsubsection{Low greenfield costs}

In this case, the foreign firm will invest greenfield in stage 2 upon losing the auction in stage 1 , as investment costs are sufficiently low, i.e. $G<\bar{G}(t)$. If the domestic firm acquires the state assets, the foreign firm invests greenfield and 
aggregate profits are $\Pi_{d}=\Pi(0)-G$. If the foreign firm acquires the state assets, investment costs are avoided and aggregate profits are $\Pi_{f}=\Pi(0)$. Consequently, we obtain the following result, illustrated by figure 3.1(iii):

Lemma 3. Assume that $G<\bar{G}(t)$, then $\Pi_{f}>\Pi_{d}$.

Intuitively, the lower greenfield cost decreases the domestic firm's willingness to pay, since the foreign firm can credibly threaten to enter greenfield, if it does not obtain the state assets. At the same time, the foreign firm is willing to pay $G$ for the state assets and obtains them.

\section{Policy}

A central question is whether the privatization procedure selects the socially most preferred buyer. A fundamental problem in determining the most preferred buyer is that the equilibrium price of the state asset is affected by government policy. The endogenous nature of the buyer's identity and the auction price in the present analysis, as well as the international dimension, imply that the optimal design of policy is very complicated. Therefore, we will make a couple of remarks on policy that might indicate areas worthy of future investigations.

\subsection{National Treatment Clauses in Privatizations}

The basic idea behind national treatment clauses is the commitment of countries to treat foreign-controlled firms operating in their territories no less favorably than domestic enterprises in similar situations. In the policy debate on FDI, it has been of concern that FDI might "crowd out" domestic investments and shift profits from domestic to foreign firms. ${ }^{22}$ Here, we will illuminate the concept of national

\footnotetext{
${ }^{22}$ World Investment Report, 1999.
} 
treatment in the context of privatizations. More specifically, we compare two policies: (i) a national treatment (NT) policy, where no discrimination between domestic and foreign buyers occurs, and (ii) a protectionism (P) policy, where only domestic buyers are allowed to acquire the state assets. ${ }^{23}$

The conventional welfare evaluation of M\&As and market structures in an international oligopoly is typically made by comparing the sum of domestic consumer surplus and domestic profits in different market structures. We follow this approach but add the sales price of the state assets into the domestic welfare measure. It then follows that the NT and P policies only differ when the foreign firm obtains the state assets under the NT policy. The reason is that the price paid by the domestic firm when obtaining the state assets does not affect the welfare level, since it is only a transfer between the domestic firm and the domestic government. Let $W_{f}^{N T}$ denote the welfare level when the foreign firm obtains the state asset under the NT policy, and let $W_{d}^{P}$ denote the welfare level under the $\mathrm{P}$ policy. Denoting the difference in welfare $W_{N T-P}$, we have that:

$$
\begin{aligned}
W_{N T-P} & =W_{f}^{N T}-W_{d}^{P} \\
& =\left[v_{d f}+C S_{f}+\pi_{d f}\right]-\left[C S_{d}+\pi_{d d}\right]
\end{aligned}
$$

There are three terms in $W_{f}^{N T}$ : First, the sale of the state assets generates revenues. As shown in Lemma 1, the foreign firm pays the valuation of the domestic firm, i.e. $v_{d f}$. The second term is the consumer surplus when the foreign firm is the equilibrium buyer, denoted $C S_{f}$. The consumer surplus depends on the trade cost faced by the foreign firm and thus $C S_{f}=C S(0)$ and $C S_{d}=C S(t)$. Finally, the domestic firm's profit when the state assets are in the hands of the foreign firm is $\pi_{d f}$.

\footnotetext{
${ }^{23}$ Note that we focus on the effects in Country $\mathrm{H}$ and thus abstract from the effects in Country F. Moreover, we abstract from how the policies are determined.
} 
$W_{d}^{P}$ are derived in the same fashion. Note that since the sales price for the state assets is just a redistribution from the domestic firm to the domestic government, the sales price is not included in $W_{d}^{P}$.

We can then rewrite (4.1):

$$
\begin{aligned}
W_{N T-P} & =v_{d f}-\left(\pi_{d d}-\pi_{d f}\right)+C S(0)-C S(t) \\
& =C S(0)-C S(t) \geq 0
\end{aligned}
$$

This (weak) inequality always holds since aggregate output will be higher in the market structure without trade costs: When greenfield entry is not credible, $G>$ $\bar{G}(t)$, foreign ownership increases consumer surplus and, hence, welfare since either the trade cost, or the monopoly position of the domestic firm is avoided. When greenfield entry is credible, $G<\bar{G}(t)$, foreign and domestic ownership lead to the same welfare, since the selling price is zero and the consumer surplus will be the same under either firm's acquisition.

Hence, we conclude:

\section{Corollary 1. The National Treatment policy yields at least as high domestic welfare as the Protectionism policy.}

The intuition of this result follows directly from the first line in (4.2): The foreign firm pays a price equal to the domestic firm's valuation of the state assets - but the domestic firm's valuation, $v_{d f}$, is precisely the negative impact on this firm through the decline in profits created by the foreign acquisition, $\pi_{d d}-\pi_{d f}$.

This result also illustrates a fundamental difference between foreign entry in the context of acquisition and greenfield investment. In the case where only greenfield entry is an option, the above reasoning concerning the consumer effect is still valid. However, the rent shifting effect will now have different welfare effects. To see this, note that, when entering, the foreign firm will pay a fixed entry cost 
$G$ which only covers the opportunity cost in terms of factor inputs. However, the negative effect on the domestic firm's profit is not "paid for". Consequently, the issue of national treatment in the context of $\mathrm{M} \& \mathrm{~A}$ differs from the context of greenfield, since in the former, but not in the latter, some of the rent shifting created by the investment is partly paid for by the foreign investor. ${ }^{24}$

\subsection{Investment and trade policy}

The preceding section dealt with the preferred buyer, taking investment and trade policy as given. We now elaborate on trade and investment policy, taking the privatization-auction, defined in Section 2.3, as given. Governments can affect investment costs in numerous ways. For instance, location subsides and tax reductions can contribute to lower investment costs. Trade policy can be performed by using tariffs or by employing various measures inhibiting import competition, such as border controls. Let us then assume that the government can affect the greenfield $\operatorname{cost} G$ and the trade cost $t$ the foreign firm must face. In order to highlight the strategic effects of the investment and trade policy, subsidies or taxes are assumed not to directly affect the government's budget. Welfare is then given

\footnotetext{
${ }^{24}$ This finding does not imply that NT policy always leads to higher welfare, however. The domestic firm might be the socially preferred buyer, if there are several domestic firms, since the acquirer does not pay for the aggregate externalities its acquisition creates. Moreover, in a more general set-up, a domestic buyer might be preferred since its acquisition might lead to more foreign greenfield investments.

Note also that a partially discriminatory policy might be socially preferred to the NT policy, since the government might then be able to capture a larger share of the foreign firm's rents. However, this issue is outside the scope of this paper.
} 
by

$W=\left\{\begin{array}{c}v_{d f}+C S_{f}+\pi_{d f}, \quad \text { when the foreign firm obtains the state assets. } \\ C S_{d}+\pi_{d d}, \quad \text { when the domestic firm obtains the state assets. }\end{array}\right.$

The design of investment and trade policy will be complicated by the fact that it does not only affect the firms' incentives for greenfield investment and exports, ${ }^{25}$ but also affects the sales price at the auction. In order to simplify the analysis, we make the following assumption:

Assumption A $1 P=1-Q$

In figure 4.1, we illustrate how welfare is affected by investment and trade policy. The corresponding equilibrium market structures are indicated by arrows.

Trade policy: Trade costs affect both the price paid at the auction and the identity of the buyer. When greenfield costs are sufficiently high and trade costs are low, $G>\bar{G}(t)$ and $t<t^{*}$, the foreign firm obtains the state assets. A small increase in trade costs then implies that the foreign firm still obtains the state assets, but must pay a higher price for these assets, since the domestic firm's valuation has increased, due to the strengthened anti-competitive effect of higher trade costs (c.f equation (3.1) ). Consequently, welfare increases since the product market equilibrium is unaffected. Thus, we have the following result: ${ }^{26}$

Corollary 2. Increased trade barriers can increase domestic welfare without increasing the profit of the domestic firm or the tax income by forcing a foreign buyer to pay more for the state assets.

\footnotetext{
${ }^{25}$ See, for instance, Markusen (1997) and Sanna-Randaccio (1996) on this issue.

${ }^{26}$ Note that this result would not be affected if revenues were assumed to be generated from trade costs, since no exports take place in equilibrium.
} 


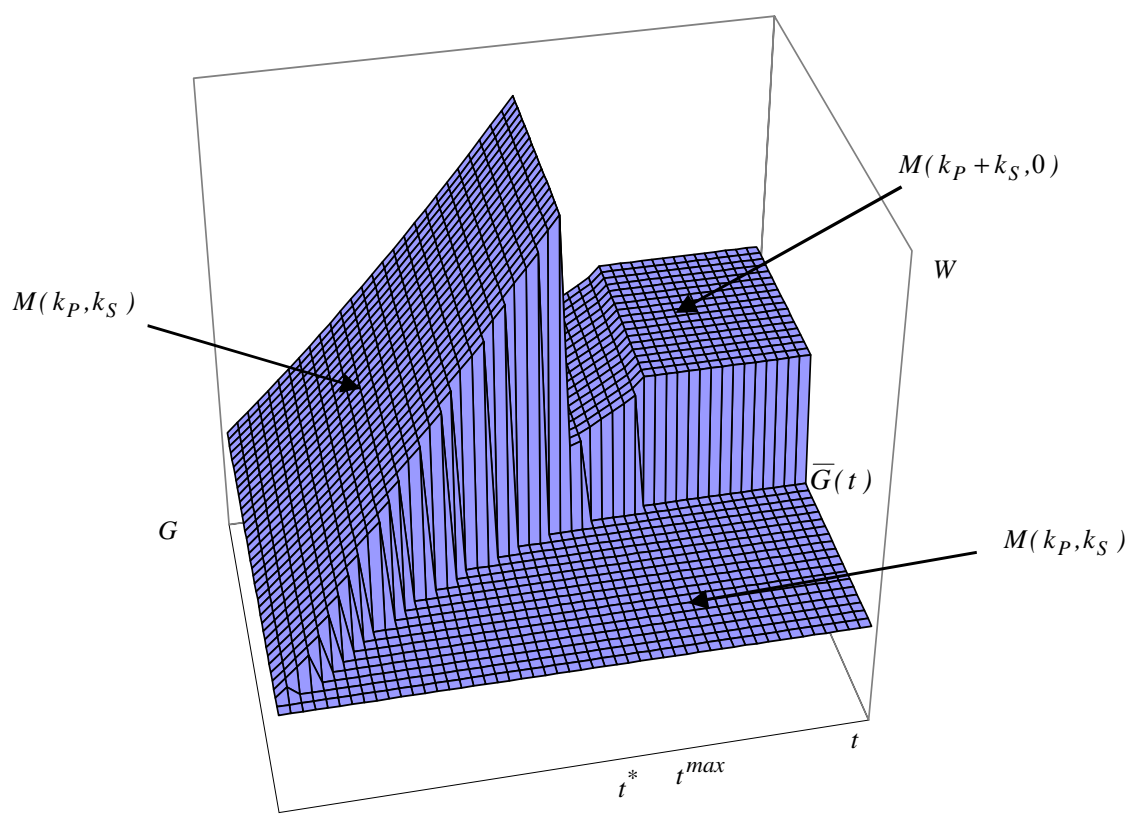

Figure 4.1: Welfare in the different market structures.

However, a larger increase might lead to the domestic firm obtaining the state assets. The government then no longer extracts foreign profits. Moreover, the domestic firm's acquisition leads to lower consumer surplus, since the price in the product market will be higher. These two effects outweigh the effect of increased profits for the domestic firm, leading to lower aggregate welfare, as shown in figure 4.1. Moreover, if trade costs are increased for medium size investment costs, this might lead to the foreign firm having a credible greenfield threat This, in turn, might lead to a loss in sales revenues as the domestic firm's valuation of the state assets falls to zero.

Investment policy: Investment subsidies might reduce welfare, also when it leads to increased investments and when associated with no direct costs. By encouraging FDI through greenfield entry, the revenues from selling the state assets decrease, since the value for the domestic firm of owning the state assets 
decreases. For example, if greenfield costs are sufficiently high and trade costs are low, that is $G>\bar{G}(t)$ and $t<t^{*}$, the foreign firm obtains the state assets. If investment costs are reduced, this might lead to a loss of sales revenues if $G$ is reduced below $\bar{G}(t)$, as the domestic firm's valuation of the state assets falls to zero. This implies that the government can no longer extract foreign profits. Since the product market equilibrium is unaffected, we have the following result: ${ }^{27}$

Corollary 3. Investment subsidies to foreign firms might reduce domestic welfare, since these do not necessarily increase investments but only reduce the sales price of the state assets.

Finally, the figure also illustrates that welfare will jump discontinuously from changes in trade and investment policy as this leads to changes in the equilibrium market structure. ${ }^{28}$ It turns out that the highest welfare in the model will be for high greenfield costs and medium high trade costs. The reason is that the sales price increases with the trade costs in this interval, as it leads to a stronger anticompetitive and business stealing effect and a weaker trade cost savings effect (c.f equation (3.1)).

\section{R obustness of results}

The model in this paper is obviously restrictive in several respects. In this section, we show that the mechanisms highlighted in the model are also at work in a more general set-up. Three different extensions will be considered separately; (a) allowing for more general assumptions about costs, demand, and mode of

\footnotetext{
${ }^{27}$ This result would be strengthened if assuming investment subsidies not to be costless.

${ }^{28}$ Horstmann and Markusen (1992) showed that these jumps are a characteristic of markets with MNEs.
} 


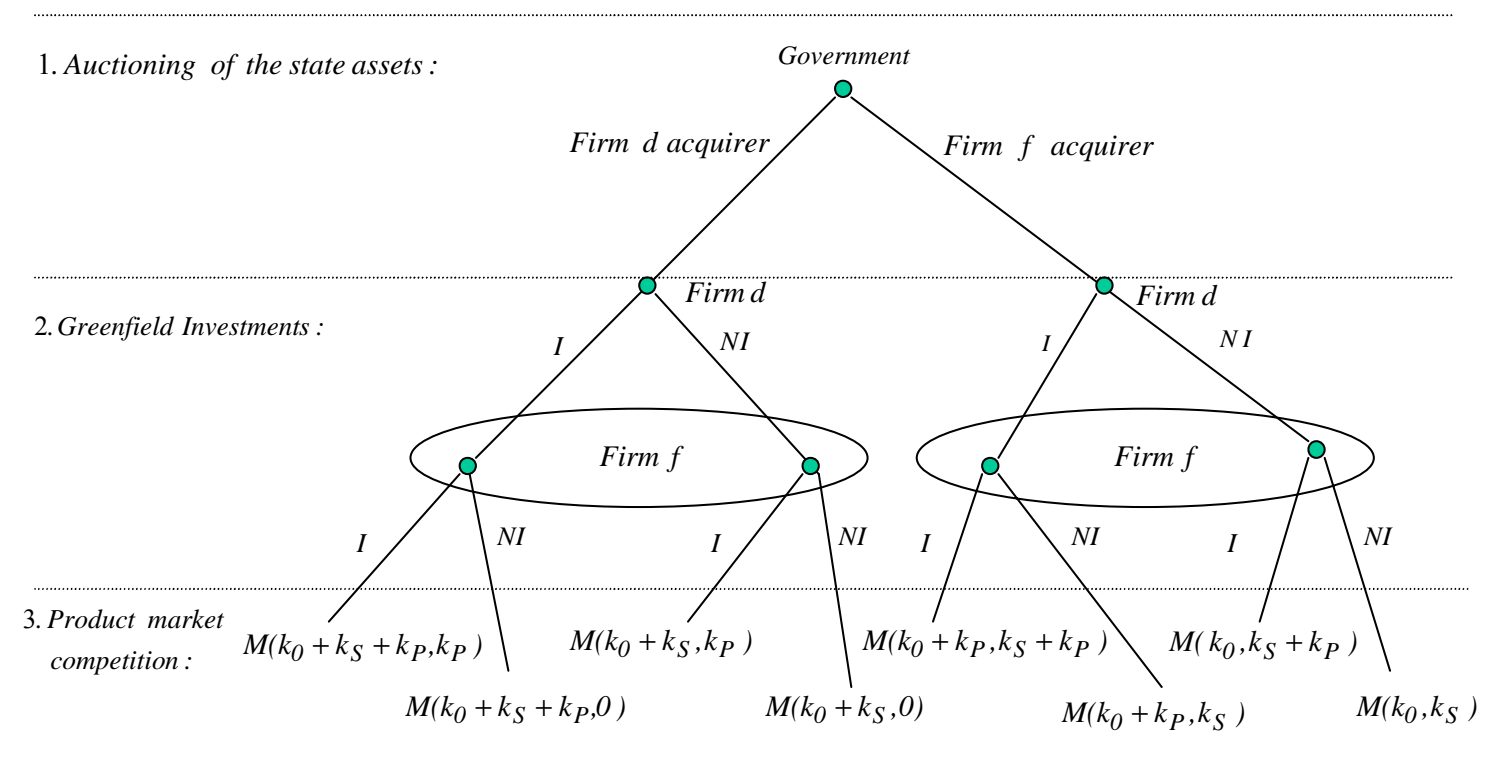

Note : I = Investments, $\mathrm{NI}=$ No Investments

Figure 5.1: The general three-stage game.

competition, (b) increasing the number of firms, and (c) allowing for exports from country $\mathrm{H}$.

\subsubsection{Assumptions on costs, demand and the mode of competition}

To this end, consider an extended version of the model as illustrated in figure 5.1. Some more notation is need before proceeding: $k_{0}$ denotes the private domestic firm's initial capital stock, whereas $k_{P}$ denotes the capital stock generated by either of the firms by investing in period 2. Let firm $w$ (winner) be the firm that obtained the state asset in period 1, and firm $l$ (loser) the firm that did not. Then, use $\pi_{w}^{k_{w}, k_{1}}(t)$ as short-hand for profits, where $k_{w}$ is the number of assets possessed by firm $w$, whereas $k_{l}$ is the number of assets in firm $l$.

For a high enough greenfield costs, it follows that no firm invests in the greenfield game in period 2. Lemma 1 then establishes that the domestic firm obtains 
the assets iff $\pi_{d}^{k_{0}+k_{\mathrm{S}}, 0}(t)+\pi_{f}^{0, k_{0}+k_{\mathrm{S}}}(t)>\pi_{f}^{k_{\mathrm{s}}, k_{0}}(0)+\pi_{d}^{k_{0}, k_{\mathrm{S}}}(0)$ and the foreign firm obtains the assets iff the inequality is reversed. It then follows that the inequality holds for a sufficiently large $t$, since the domestic firm becomes a monopolist if obtaining the state assets. Moreover, if cost synergies are assumed to be associated with combining the state assets with private assets, the reasoning above also holds.

Second, the observation that low greenfield costs for foreign firms lead to foreign acquisitions is not specific to the above model either. To see this, consider the situation where the foreign firm, but not the domestic firm, would invest greenfield if the other firm obtained the state assets, and where no firm would make an additional investment. It then follows from Lemma 1 that the foreign firm obtains the assets iff $\pi_{f}^{k_{\mathrm{S}}, k_{0}}(0)+\pi_{d}^{k_{0}, k_{\mathrm{S}}}(0)>\pi_{d}^{k_{0}+k_{\mathrm{S}}, k_{\mathrm{N}}}(0)+\pi_{f}^{k_{\mathrm{N}}, k_{0}+k_{\mathrm{S}}}(0)-G_{f}^{N}$, where $G_{f}^{N}$ denotes the greenfield cost of the foreign firm. This inequality holds as long as the increase in aggregate profits from adding new capital is less than the cost for the foreign firm, $G_{f}^{N}$. Since a decrease in the foreign firm's variable cost typically decreases the domestic firm's profits, this inequality will hold in several oligopoly models for some parameter values.

Thus, the finding that low greenfield costs and low trade costs are conducive to foreign acquisitions and high greenfield costs and high trade costs are conducive to domestic acquisitions is not specific to the model presented above.

\subsubsection{More firms}

Consider a situation with $D$ domestic firms and $F$ foreign firms. Let $\pi_{D_{1}}^{k_{\mathrm{s}}, 0}(t ; 1, D-$ $1, F, 0)$ denote the profit for the domestic firm, $D_{1}$, when it obtains the state assets and no firm invests in period 2 , and $\pi_{F_{1}}^{0, k_{\mathrm{S}}}(t ; 1, D-1, F, 0)$ the profit for the foreign firm $F_{1}$ when $D_{1}$ obtains the state assets and no firm invests in period 2. The second entry in the parenthesis refers to the number of firms with both state 
assets and private assets, the third entry refers to the number of single asset domestic firms, the fourth entry refers to the number of foreign firms which have not invested in country $\mathrm{H}$ and the fifth entry refers to the number of foreign firms having invested in country $\mathrm{H}$.

For high enough greenfield costs, it follows that no firm invests in the greenfield game in period 2. From the same reasoning as in the proof of Lemma 1, it follows that there exists an equilibrium where a domestic firm obtains the state assets if $\pi_{D_{1}}^{k_{\mathrm{s}}, 0}(t ; 1, D-1, F, 0)+\pi_{F_{1}}^{0, k_{\mathrm{s}}}(t ; 1, D-1, F, 0)>\pi_{D_{1}}^{0, k_{\mathrm{s}}}(t ; 0, D, F-1,1)+$ $\pi_{F_{1}}^{k_{\mathrm{s}}, 0}(t ; 0, D, F-1,1)$. This condition holds for a sufficiently large $t$ and for sufficiently large cost synergies associated with combining the state assets with private assets. $^{29}$

For low enough greenfield costs, it follows that foreign firms invest in the greenfield game in period 2. From the same reasoning as in the proof of Lemma 1 , it then follows that there exists an equilibrium where a foreign firm obtains the state assets if $\pi_{D_{1}}^{0, k_{\mathrm{S}}}(t ; 0, D, 0, F)+\pi_{F_{1}}^{k_{\mathrm{s}}, 0}(t ; 0, D, 0, F)>\pi_{D_{1}}^{k_{\mathrm{s}}, k_{\mathrm{N}}}(t ; 1, D-1,0, F)+$ $\pi_{F_{1}}^{k_{\mathrm{N}}, k_{\mathrm{S}}}(t ; 1, D-1,0, F)-G$, which holds in this setting since $\pi_{D_{1}}^{0, k_{\mathrm{S}}}(t ; 0, D, 0, F)=$ $\pi_{D_{1}}^{k_{\mathrm{s}}, k_{\mathrm{N}}}(t ; 1, D-1,0, F)$ and $\pi_{F_{1}}^{k_{\mathrm{s}}, 0}(t ; 0, D, 0, F)=\pi_{F_{1}}^{k_{\mathrm{N}}, k_{\mathrm{s}}}(t ; 1, D-1,0, F)$.

Thus, the finding that low greenfield costs and low trade costs are conducive to foreign acquisitions and high greenfield costs and high trade costs are conducive to domestic acquisitions extends to a multi-firm setting.

\footnotetext{
${ }^{29}$ Note that in the Cournot model, with two domestic firms or more, without complementarity between state and private assets, it can be shown that the foreign firm will always acquire the SOE. On the other hand, if firms compete a la Bertrand with differentiated products, the result that a domestic firm acquires the state assets at high trade costs holds. The reason is that all firms benefit from a domestic firm obtaining the state assets, since higher trade costs weaken price competition.
} 


\subsubsection{Bilateral trade and investments}

Consider now a situation where the domestic firm could export or invest in the market in country F. Assume the markets to be segmented on the demand side. It then follows that the results derived in the model still hold. To see this, note that the domestic firm's costs are not affected by whether it obtains the state assets. Furthermore, note that a foreign firm will never export from its foreign location to its home country, since its costs are at least as low producing in its domestic market. Consequently, allowing for exports and foreign investment by the domestic firm will not affect the results derived here. If there are cost synergies associated with combining the state assets with private assets, the analysis will be more complicated, however, since a domestic firm's level of exports might be affected by whether it obtains the state assets or not. However, the same reasoning as for the proof of Lemma 1 still applies, so that the aggregate profits in the market play an important role as the determinant of the equilibrium buyer. Consequently, the mechanisms identified here still play a role for determining the equilibrium buyer.

\section{Concluding discussion}

This paper determines the emerging equilibrium market structure in a mixed international oligopoly where the state enterprise is sold at an auction. The model suggests that low greenfield costs and low trade costs induce foreign acquisitions. The reason is that domestic firms can then not prevent foreign firms from becoming locally strong competitors and thus, their willingness to pay for the state assets are low.

The paper points to the fact that the potential negative effects of a national treatment clause through crowding out is partly mitigated in privatizations, since 
the negative impact on domestic firms created by the acquisition is partly paid for by the foreign investor in the bidding competition over the state assets. The paper also points to the fact that investment and trade policies can be used strategically to improve the outcome of the privatization procedure by increasing the selling price.

The issue of optimal design of the privatization policy has not been addressed here. The complexity of the externalities involved in the selling of the state assets indicates that informational constraint will be important for deriving optimal policies. A natural step, however, is to explicitly model this restriction and to investigate whether selling rules incurring a higher welfare level than the ones using only information about nationality, might be found. 


\section{A. A ppendix}

\section{A.1. Proof of Lemma 1}

In this proof, we will use the following more general notation of the valuation of the state-assets: Generally, the valuations of the state assets do not only depend on the identity of firm $i$, but also on the identity of the firm obtaining the assets, firm $j$, and on the identity of the firm that will obtain the assets if firm $j$ does not, that is, firm $h$. Some notation is required in order to define a firm's valuation. Let $\mathbf{K} \equiv\left(k_{1}, k_{2}, k_{s}\right)$. Let $\mathbf{K}^{j}$ denote the vector of capital stocks after firm $j$ has obtained the state assets and $\pi_{i}\left(\mathbf{K}^{j}\right)$ denote the profit made by firm $i$ when firm $j$ has acquired the state assets. Then, the valuation for firm $i, v_{i}^{j h}$, is defined as $v_{i}^{j h} \equiv \pi_{i}\left(\mathrm{~K}^{j}\right)-\pi_{i}\left(\mathrm{~K}^{l}\right)$.

Let $v_{i}^{i j}>v_{j}^{j i}$ without loss of generality. First, consider the equilibrium candidate where firm $i$ acquires the state assets. Consider the equilibrium candidate $\mathbf{b}^{*}$, where $b_{i}^{*}>b_{j}^{*}, j \neq i$. Let owner $i$ be the owner obtaining the state assets. Note that $b_{i}^{*}>v_{i}^{i j}$ is a weakly dominated strategy, since no owner will post a bid over its maximum valuation of obtaining the assets. If $b_{i}^{*}<v_{j}^{j i}$, firm $j$ benefits from deviating to $b_{j}^{* *}=b_{i}^{*}+\varepsilon$, since it then obtains the assets according to Definition 1 and pays a price for the assets which is lower than its valuation of obtaining them. Last, consider candidate $b_{i}^{*}=v_{j}^{j i}, . b_{j}^{*}=v_{j}^{j i}-\varepsilon$. Then, no owner has an incentive to deviate. Thus, this is a Nash equilibrium and the only NE where firm $i$ obtains the assets.

Let us now show that this is the only Nash equilibrium.

First, consider the situation where firm $j$ obtains the assets. Consider the equilibrium candidate $\mathrm{b}^{*}$, where $b_{j}^{*}>b_{i}^{*}, j \neq i$. But we know that in equilibrium, $b_{j}^{*}<v_{j}^{j i}$, since firm $j$ otherwise plays a weakly dominated strategy. But if $b_{j}^{*}<v_{j}^{j i}$, 
firm $i$ benefits from deviating to $b_{i}^{* *}=b_{j}^{*}+\varepsilon$, since it then obtains the assets according to Definition 1 and pays a price for the assets which is lower than its valuation of obtaining them. Thus, firm $j$ obtaining the assets is not an equilibrium.

Second, note that the situation where neither firm $i$ nor firm $j$ obtains the assets cannot occur if there is no reservation price at the auction.

\section{A.2. Proof of Proposition 1}

Lemma 1 implies that the firm with the highest valuation, firm $i$, obtains the assets at a price $v_{j i}$.

(i) If $G>\bar{G}(t)$ and $t>t^{*}$. In this interval, firm $f$ will not undertake a greenfield investment. It then follows from Lemma 2 that firm $d$ obtains the assets at a price $\pi_{f}^{d}(0)$, when $t \geq t^{\max }$, and at a price $\pi_{f}^{d}(0)-\pi_{f}^{d}(t)$ when $t<t^{\max }$.

(ii) If $G>\bar{G}(t)$ and $t<t^{*}$. In this interval, firm $f$ will not undertake a greenfield investment. It then follows from Lemma 2 that firm $f$ obtains the assets at a price $\pi_{d}^{d}(t)-\pi_{d}^{d}(0)$.

(iii) If $G<\bar{G}(t)$. In this interval, firm $f$ will undertake a greenfield investment. It then follows from Lemma 3 that firm $f$ obtains the assets at a price 0 .

\section{A.3. Derivation of (3.1)}

Aggregate profit, $\Pi=\pi_{d}+\pi_{f}$, where

$$
\begin{aligned}
& \pi_{d}=P\left(q_{d}+q_{f}\right) q_{d} \\
& \pi_{f}=P\left(q_{d}+q_{f}\right) q_{f}-t q_{f}
\end{aligned}
$$


The FOCs are:

$$
\begin{aligned}
& \frac{\partial \pi_{d}}{\partial q_{d}}=P+P^{\prime} q_{d}=0 \\
& \frac{\partial \pi_{f}}{\partial q_{f}}=P+P^{\prime} q_{f}-t=0
\end{aligned}
$$

Differentiating (A.3) (A.4) wrt $q_{d}, q_{f}$, and $t$ and solving for $\frac{d q_{\mathrm{d}}}{d t}, \frac{d q_{\mathrm{f}}}{d t}$ and $\frac{d Q}{d t}$ implies

$$
\begin{aligned}
& \frac{d q_{d}}{d t}=-\frac{P^{\prime}+P^{\prime \prime} q_{d}}{D}>0, \quad \frac{d q_{f}}{d t}=\frac{2 P^{\prime}+P^{\prime \prime} q_{d}}{D}<0, \\
& \frac{d Q}{d t}=\frac{P^{\prime}}{D}<0,
\end{aligned}
$$

where $D=P^{\prime}\left[3 P^{\prime}+P^{\prime \prime} Q\right]>0$ and $Q=q_{d}+q_{f}$. We can then define aggregate profits as a function of $t$ :

$$
\Pi(t)=\pi_{d}\left(q_{d}(t), q_{f}(t), t\right)+\pi_{f}\left(q_{d}(t), q_{f}(t), t\right)
$$

Taking the total derivative in $t$ and using (A.1), (A.2), (A.3) and (A.4), (A.6) can be written:

$$
\frac{d \Pi}{d t}=P^{\prime} q_{d} \frac{d q_{f}}{d t}+P^{\prime} q_{f} \frac{d q_{d}}{d t}-q_{f}
$$

Using the first-order conditions (A.3) and (A.4) and that $\frac{d Q}{d t}=\frac{d q_{\mathrm{d}}}{d t}+\frac{d q_{\mathrm{f}}}{d t}$ must hold, (A.7) can be rewritten as:

$$
\frac{d \Pi}{d t}=P^{\prime} q_{d} \frac{d Q}{d t}+t \frac{d q_{d}}{d t}-q_{f}
$$

\section{A.4. P roof of Lemma 2}

First, we rewrite $\Pi(t)$ by inserting (A.5) into (A.7). Defining the elasticities $\beta_{Q}=\frac{P^{\infty}}{P^{0}} Q$ and $\beta_{q_{\mathrm{d}}}=\frac{P^{\infty}}{P^{0}} q_{d}$, (A.7) can be written:

$$
\frac{d \Pi(t)}{d t}=\frac{q_{d}+\left(1+\beta_{q_{\mathrm{d}}}\right)\left(q_{d}-q_{f}\right)-\left(3+\beta_{Q}\right) q_{f}}{3+\beta_{Q}}
$$

We then proceed by deriving the following Lemma: 
Lemma 4. (i) $\frac{d \Pi}{d t}(0)<0$, (ii) $\Pi\left(t^{\max }\right)>\Pi(0)$, and (iii) $\Pi(t)$ has a global minimum $\tilde{t}$ for $t \in\left[0, t^{\max }\right]$.

P roof. If demand $P(Q)$ is concave $\beta_{Q} \geq 0$ and $\beta_{q_{\mathrm{d}}} \geq 0$, since $P^{\prime}<0$ and $P^{\prime \prime} \leq 0$. Then:

(i) At $t=0$, we must have $q_{d}=q_{f}$, which implies $\frac{d \Pi}{d t}(0)=-q \frac{2+\beta_{\mathrm{Q}}}{3+\beta_{\mathrm{Q}}}<0$.

(ii) At $t=t^{\max }$, firm $d$ becomes a monopolist and thus $\Pi\left(t^{\max }\right)>\Pi(0)$.

(iii) Define $\tilde{t}$ by $\frac{d \Pi}{d t}(\tilde{t})=0$. Using (A.9), and the definitions of $\beta_{Q}$ and $\beta_{q_{\mathrm{d}}}$, this condition can be written:

$$
\frac{q_{d}}{q_{f}}-1-\frac{2 P^{\prime}+P^{\prime \prime} Q}{2 P^{\prime}+P^{\prime \prime} q_{d}}=0
$$

Again, note that $\frac{d \Pi}{d t}(0)=-q \frac{2+\beta_{\mathrm{Q}}}{3+\beta_{\mathrm{Q}}}<0$. Also, note that $\lim _{\varepsilon \rightarrow 0} \frac{d \Pi}{d t}\left(t^{\max }-\varepsilon\right)=\infty$. Then, since $\frac{q_{\mathrm{d}}}{q_{\mathrm{f}}}-1$ is monotonically increasing in $t$, whereas $\frac{2 P^{0}+P^{\infty}}{2 P^{0}+P^{\infty} q_{\mathrm{d}}}$ is strictly positive and monotonically decreasing in $t$, we know that the sign $\left(\frac{d \Pi}{d t}\right)$ changes only once and hence, the aggregate profit $\Pi(t)$ has a unique global minimum at $t=\tilde{t}$

\section{A.5. Derivation of Figure 4.1}

The figure is derived under Assumption A1.

\section{A.5.1. Period 3}

Quantities and profits in the three market structures are given in Figure A.1.

\section{A.5.2. Period 2}

From the information in Figure A.1, it can be shown that (2.1), that is, the combination of greenfield costs and trade costs at which firm $f$ is indifferent 


\begin{tabular}{||c|c|c|c|c||}
\hline \hline & \multicolumn{2}{|c|}{$M\left(k_{P}+k_{S}, 0\right)$} & $M\left(k_{P}, k_{S}\right)$ & $M\left(k_{P}+k_{S}, k_{P}\right)$ \\
& $t \leq \frac{1}{2}$ & $t>\frac{1}{2}$ & & $\frac{1}{3}$ \\
\hline$q_{d}$ & $\frac{1+t}{3}$ & $\frac{1}{2}$ & $\frac{1}{3}$ & $\frac{1}{3}$ \\
\hline$q_{f}$ & $\frac{1-2 t}{3}$ & 0 & $\frac{1}{3}$ & $\frac{2}{3}$ \\
\hline$Q$ & $\frac{2-t}{3}$ & $\frac{1}{2}$ & $\frac{2}{3}$ & $\frac{1}{9}$ \\
\hline$\pi_{d}$ & $\left(\frac{1+t}{3}\right)^{2}$ & $\frac{1}{4}$ & $\frac{1}{9}$ & $\frac{1}{9}-G$ \\
\hline$\pi_{f}$ & $\left(\frac{1-2 t}{3}\right)^{2}$ & 0 & $\frac{1}{9}$ & \\
\hline \hline
\end{tabular}

Figure A.1: Quantities and profits in the different market structures.

between setting up a new plant and exporting, can be written as:

$$
\tilde{G}= \begin{cases}\frac{4}{9} t(1-t) & \text { if } t \leq \frac{1}{2} \\ \frac{1}{9} & \text { if } t>\frac{1}{2}\end{cases}
$$

where $t^{\max }=\frac{1}{2}$.

\section{A.5.3. Period 1}

Figure A.2 summarizes the firms' valuations $v_{f d}$ and $v_{d f}$, the equilibrium market structure $M\left(k_{d}, k_{f}\right)$, consumer surplus $C S$, revenues for the government $R$ and welfare $W$. 


\begin{tabular}{|c|c|c|c|c|}
\hline & $t \leq \frac{2}{5}$ & $\begin{aligned} G & >\bar{G}(t) \\
& t \in\left(\frac{2}{5}, \frac{1}{2}\right]\end{aligned}$ & $t>\frac{1}{2}$ & $\begin{array}{l}G<\bar{G}(t) \\
\forall t\end{array}$ \\
\hline$v_{f d}$ & $\begin{array}{l}\left(\frac{1+t}{3}\right)^{2}-\left(\frac{1}{3}\right)^{2} \\
\left(\frac{1}{3}\right)^{2}-\left(\frac{1-2 t}{3}\right)^{2}\end{array}$ & $\begin{array}{l}\left(\frac{1+t}{3}\right)^{2}-\left(\frac{1}{3}\right)^{2} \\
\left(\frac{1}{3}\right)^{2}-\left(\frac{1-2 t}{3}\right)^{2}\end{array}$ & $\begin{array}{l}\left(\frac{1}{2}\right)^{2}-\left(\frac{1}{3}\right)^{2} \\
\left(\frac{1}{3}\right)^{2}-0\end{array}$ & $\begin{array}{l}\left(\frac{1}{3}\right)^{2}-\left(\frac{1}{3}\right)^{2} \\
\left(\frac{1}{3}\right)^{2}-\left(\left(\frac{1}{3}\right)^{2}-G\right)\end{array}$ \\
\hline$M\left(k_{d}, k_{f}\right)$ & $M\left(k_{P}, k_{S}\right)$ & \multicolumn{2}{|c|}{$M\left(k_{P}+k_{S}, 0\right)$} & $M\left(k_{P}, k_{S}\right)$ \\
\hline$C S$ & $\begin{array}{l}\frac{1}{2}\left(\frac{2}{3}\right)^{2} \\
\left(\frac{1+t}{3}\right)^{2}-\left(\frac{1}{3}\right)^{2}\end{array}$ & $\begin{array}{l}\frac{1}{2}\left(\frac{2-t}{3}\right)^{2} \\
\left(\frac{1}{3}\right)^{2}-\left(\frac{1-2 t}{3}\right)^{2}\end{array}$ & $\begin{array}{l}\frac{1}{2}\left(\frac{1}{2}\right)^{2} \\
\left(\frac{1}{3}\right)^{2}\end{array}$ & $\begin{array}{l}\frac{1}{2}\left(\frac{2}{3}\right)^{2} \\
\left(\frac{1}{3}\right)^{2}-\left(\frac{1}{3}\right)^{2}\end{array}$ \\
\hline$W$ & $\begin{array}{l}\left(\frac{1+t}{3}\right)^{2}-\left(\frac{1}{3}\right)^{2}+ \\
\frac{1}{2}\left(\frac{2}{3}\right)^{2}+\left(\frac{1}{3}\right)^{2}\end{array}$ & $\frac{1}{2}\left(\frac{2-t}{3}\right)^{2}+\left(\frac{1+t}{3}\right)^{2}$ & $\frac{1}{2}\left(\frac{1}{2}\right)^{2}+\left(\frac{1}{2}\right)^{2}$ & $\begin{array}{l}\left(\frac{1}{3}\right)^{2}-\left(\frac{1}{3}\right)^{2}+\frac{1}{2}\left(\frac{2}{3}\right)^{2}+ \\
\left(\frac{1}{3}\right)^{2}\end{array}$ \\
\hline
\end{tabular}

Figure A.2: The firms valuations, the equilibrium market structure, sales price of the state assets, consumer surplus and welfare. 


\section{R eferences}

[1] Bjorvatn, K., 2000, "Mode of entry: Exports, greenfield, or acquisition, Mimeo, LOS, Bergen.

[2] Cornelli, F., and Li, D., D., 1997, "Large Shareholder, Private Benefits of Control, and Optimal Schemes of Privatization, "RAND Journal of Economics," Vol. 28, No.4, pp. 585-604.

[3] Dagens Industri, 2000, June 30.

[4] Dunning, J., Trade, 1977, Location of Economic Activity and the MNE: A Search for and Eclectic Approach, in: Ohlin, B. Hesselborn, P.-O. and P.M. Wijkman, eds, The International Allocation of Economic Activity, (London: McMillan) 395-418.

[5] Financial Times, 2000, June 29.

[6] FT Euro: European Economic and Monetary Union, Quarterly Review, 1999, December 3.

[7] Fosfuri, A., Motta, M., and Ronde, T., 2000, Foreign Direct Investment and Spillovers through Workers' Mobility, Journal of International Economics (forthcoming).

[8] Görg, H., 1998, "Analyzing Foreign Market Entry: The Choice between Greenfield Investment and Acquisition," Working Paper No. 98/1, (Trinity Economic Paper Series).

[9] Horn, Henrik and L. Persson, 2000, "The Equilibrium Ownership of an International Oligopoly," Journal of International Economics (forthcoming). 
[10] Horstmann, I. and J. Markusen, 1992, Endogenous Market Structures in International Trade (Natura Facit Saltum), Journal of International Economics 32, 109-129.

[11] Jehiel, P. and Moldovanu, B., 1996, "Strategic Nonparticipation," RAND Journal of Economics, Vol. 27, 84-98.

[12] Jehiel, P., Moldovanu, B., and Stacchetti, E., 1996, "How (Not) to Sell Nuclear Weapons," American Economic Review, September, Vol. 86, 814-829.

[13] Jehiel, P., Moldovanu, B., and Stacchetti, E., 1999, "Multidimensional Mechanism Design for Auctions with Externalities," Journal of Economic Theory 85(2), 258-294.

[14] Lopez-de-Silanes, F., 1997, "Determinates of Privatization Prices," Quarterly Journal of Economics, Vol. CXII, 965-1025.

[15] Markusen, J. R., 1995, The Boundaries of Multinational Enterprises and the Theory of International Trade, Journal of Economic Perspective 9, 169-189.

[16] Markusen, J. R., 1997, "Trade versus Investment Liberalization," National Bureau of Economic Research Working Paper No. 6231.

[17] Markusen, J. R. and A. Venables, 1998, Multinational Firms and the New Trade Theory, Journal of International Economics 46, 183-203.

[18] Motta, M , 1992 "Multinational Firms and the Tariff-Jumping Argument": A game Theoretic Analysis with some Unconventional Conclusions", European Economic Review, December No 8, 1557-71.

[19] Sanna-Randaccio, F , 1996 "New Protectionism and Multinational Companies", Journal of International Economics 41, 29-51. 
[20] Schmidt, K., M., and Schnitzer, M., 1997, "Methods of Privatization: Auctions, Bargaining and Give-aways," Discussion Paper 1541, Centre for Economic Policy Research.

[21] The Economist, 1998, October 24 and 2000, July 15.

[22] UNCTAD, World Investment Report 1998 and 1999, (United Nations Conference on Trade and Development, Geneva).

[23] UNCTAD, 1999, "The role of competition policy for development in globalizing world markets, (United Nations Conference on Trade and Development, Geneva).

[24] Vickers, J, and Yarrow, G., 1991, "Economic Perspectives on Privatization", Journal of Economic Perspectives, Vol.5, No. 2, 111-132. 